\title{
"A mulher da guerra": Influências e inspirações para a criação de uma coleção de moda
}

SILVEIRA, Laiana; Graduanda em Design de Moda; Instituto Federal Sul-Rio-Grandense Campus Pelotas Visconde da Graça laianasilveira@gmail.com

Orientador: SCHNEID, Frantieska; Doutoranda e Mestre em Memória Social e Patrimônio Cultural; Universidade Federal de Pelotas

frantieskahs@gmail.com

Palavras-Chave: Segunda Guerra Mundial, Mulher, Vestimenta, Escassez, Versatilidade, Coleção de moda.

Resumo: O presente trabalho possui como temática principal, o conflito histórico da Segunda Guerra Mundial, e a partir desta proposta, procurou-se encontrar uma delimitação de tema com informações e detalhes suficientes para a pesquisa e desenvolvimento de uma coleção de moda, escolheu-se ressaltar a versatilidade da roupa feminina durante a guerra, sabendo que nesse período a mulher que era considerada frágil, e viu-se obrigada a mudar sua rotina, assumir postura forte, sair do lar para trabalhar, ou seja, de dona de casa a operária.

\section{Introdução}

O fim dos anos de 1930 foi marcado pelo início da Segunda Guerra Mundial, envolvendo inúmeras nações do mundo e que mudou os rumos da história, deixando marcas até a atualidade. A moda começou a ganhar influência da vestimenta masculina pelos uniformes usados pelos soldados, o guarda-roupa feminino tornou-se mais sóbrio, rígido e prático, pois o essencial era ter somente o que fosse preciso para uma possível fuga.

Tema que traz a importância da mulher neste período, visto que a mesma mostrou ao mundo a força da sua independência, e que ela foi fundamental para que as fábricas não parassem de funcionar. Sabe-se que a Segunda Guerra mudou o formato das roupas, devido ao racionamento de tecidos e regulamentação do seu uso, portanto, a moda precisou adaptar-se as circunstâncias precárias, e as peças precisavam ser práticas e confortáveis para o seu uso.

Através da pesquisa realizada e da elaboração de um book criativo, pode-se desenvolver uma coleção de moda inspirada no período histórico abordado voltada ao público feminino, buscando a funcionalidade das peças.

\section{A Segunda Guerra como inspiração para o desenvolvimento de uma coleção de moda}


Uma década que inicia devastada pela guerra, e que a silhueta final dos anos 30, em estilo militar, formas mais retas e rígidas serão trazidas para a coleção. Já introduzindo a questão têxtil, a autora Pollini diz que, "em 1941, entrou em voga o "Cartão do Vestuário", que determinava a quantidade de roupas que os franceses podiam consumir" (POLLINI, 2007, p. 59), o governo impôs a população o uso do cartão.

Esta solução criada e imposta pelo governo foi mal recebida por todos, porém, era necessária diante das circunstâncias do período. As dificuldades encontradas pelos consumidores fizeram com que eles buscassem novas alternativas para suprir suas necessidades, um exemplo é a lã que custava menos cupons do que a roupa pronta; portanto, tricotar era econômico e útil, as mulheres viam-se obrigadas a comprar lã e confeccionar suas próprias roupas como forma de economia.

Devido a escassez, a roupa ficou marcada pela função utilitária e sem muitos detalhes, podendo assim observar a uniformização da mesma, com ares masculinizados, com o uso dos ombros acentuados com ombreiras e corte reto. Neste período, junto com a recessão, surgiu o reaproveitamento de tecidos e peças que já não eram mais utilizadas, tornando útil qualquer artigo de vestuário que já havia sido tirado de uso. As peças-chave da coleção desenvolvida foram vestidos alongados que podem ser usados como casacos, com tecidos mais pesados.

A moda na primeira metade da década chega sem cores e rígida, limitada pelo governo, segundo Mackenzie existiu um manual de produção do vestuário com critérios restritivos "limitando o uso de botões e bolsos, reduzindo costuras e bainhas e fixando até o número de pregas para as saias. Todos os enfeites eram proibidos" (MACKENZIE, 2010, p. 84). A vestimenta estava caracterizada pela ausência de variação. A ordem da vez era economizar, a situação permitiu que a população explorasse melhor a criatividade. A moda feminina agora era totalmente influenciada pela masculina.

\section{Coleção A mulher da guerra}

O intuito do presente trabalho foi a criação de uma coleção de moda inspirada na 
Segunda Guerra Mundial, apresentando como delimitação de tema a mulher que precisou sair de casa para trabalhar. Através da pesquisa bibliográfica e da criação do book criativo, conseguiu-se criar uma coleção com dez looks comerciais e uma saia conceitual. Pode-se observar na Figura 1, a coleção desenvolvida.
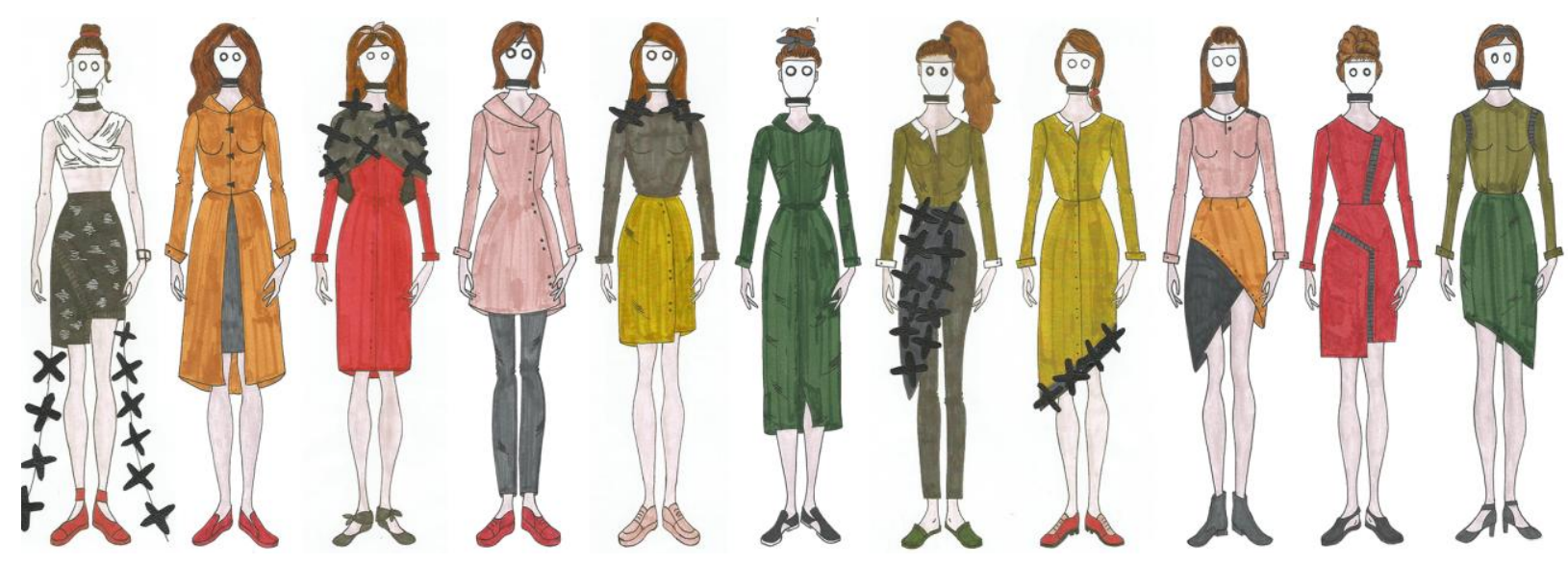

Figura 1 - Coleção desenvolvida

Fonte - Elaborada pelo autor

Está presente na coleção o corte reto relembrando as roupas rígidas do período, tons frios como verde e cinza, aviamentos utilitários como botões e zípers e a maior parte da coleção é composta por vestidos-casacos que é uma peça versátil. Está presente também na coleção a assimetria, o destroyed em algumas peças de sarja, a aplicação de flores em courino.

\section{Considerações finais}

Conclui-se que o período da Segunda Guerra trouxe inspiração para a coleção desenvolvida, pensada nas mulheres que firmaram sua independência, lutando para sustentar suas famílias, e que apesar de jornadas de trabalho, não deixavam de lado os cuidados com a vestimenta. Esse período trouxe também mudanças para a moda, através da criatividade usada por todos perante uma situação de escassez têxtil e um regime estritamente controlador.

\section{Referências}


MACKENZIE, M. Ismos: para entender a moda / Mairi Mackenzie; Tradução Christiano Sensi. - São Paulo: Editora Globo, 2010.

POLLINI, D. Breve história da moda. São Paulo: Editora Claridade, 2007 / Coleção Saber de tudo. 